\title{
Finger Lime: An Alternative Crop with Great Potential in South Florida'
}

\author{
Aditya Singh, Edward Evans, Jeff Wasielewski, Manjul Dutt, and Jude Grosser ${ }^{2}$
}

\section{Introduction}

Florida's tropical fruit industry acreage has fluctuated since the 1970s due to natural disasters, foreign competition, and US demographic changes. The state has approximately 1,650 commercial tropical fruit producers growing over 30 different species of fruits. Production occurs on about 16,000 acres, with an economic impact of over $\$ 137$ million annually. Approximately $85 \%$ of the commercial acreage is located in Miami-Dade County, with the remainder in Brevard, Broward, Charlotte, Collier, Indian River, Lee, Martin, Palm Beach, Pasco, St. Lucie, and Sarasota Counties.

Challenges to the Florida tropical fruit industry include more foreign competition, higher domestic labor costs, stringent US environmental regulations, and an increase in invasive alien pests and diseases in the state (Shannon 2003). The sum effect is that Florida's growers are finding it difficult to compete in some of the markets for traditional tropical fruit crops and are actively searching for alternative niche-market crops that offer the potential of relatively high returns. Consequently, the aim of this article is to draw attention to a potential alternative niche crop, namely finger limes. Currently, commercial production of this crop in the United States is extremely limited, and data on the agronomic and economic aspect of domestically producing and marketing the crop are sparse and, in most cases,

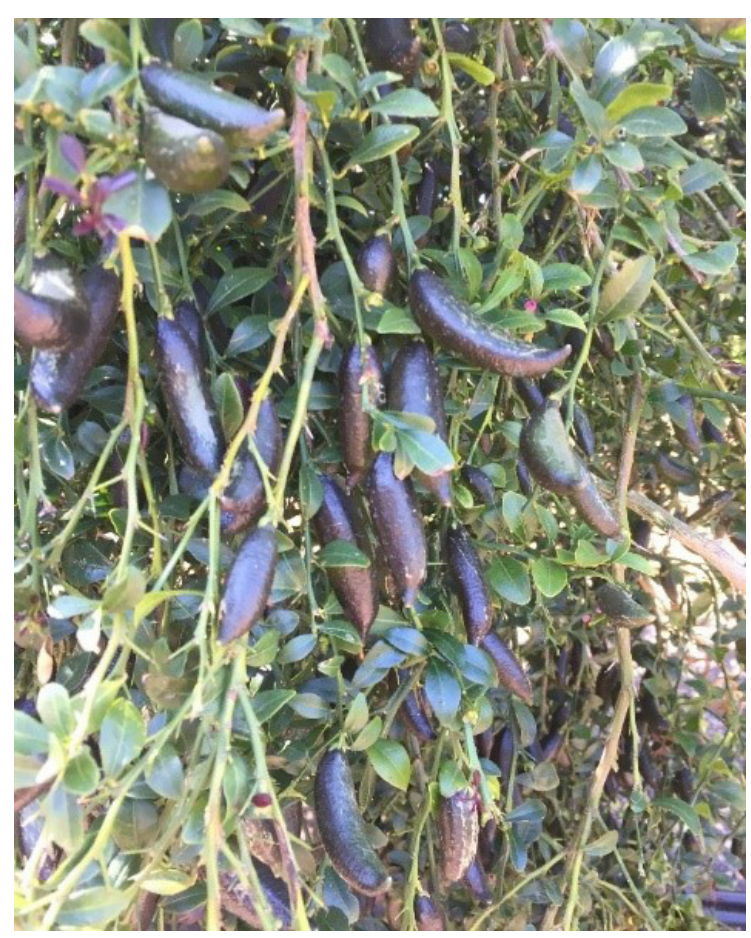

Credits: Jeff Wasielewski, UF/IFAS Extension

unavailable, resulting in the need to rely on information sourced from abroad. Notwithstanding the paucity of data, the article provides some insights of potential returns associated with this crop.

1. This is EDIS document FE1033, a publication of the Food and Resource Economics Department, UF/IFAS Extension. Published October 2017. Visit the EDIS website at http://edis.ifas.ufl.edu.

2. Aditya Singh, research scholar, Food and Resource Economics Department, UF/IFAS Tropical Research and Education Center, Homestead, FL; Edward Evans, interim center director and professor, Food and Resource Economics Department, UF/IFAS Tropical Research and Education Center, Homestead, FL; Jeff Wasielewski, commercial tropical fruit crops extension agent, UF/IFAS Miami-Dade County Extension Office, Homestead, FL; Manjul Dutt, research assistant scientist, horticultural sciences, UF/IFAS Citrus Research and Education Center, Lake Alfred, FL; and Jude Grosser, professor, plant cell genetics, UF/IFAS Citrus Research and Education Center, Lake Alfred, FL.

The Institute of Food and Agricultural Sciences (IFAS) is an Equal Opportunity Institution authorized to provide research, educational information and other services

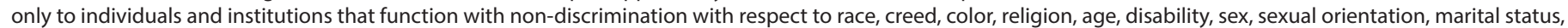

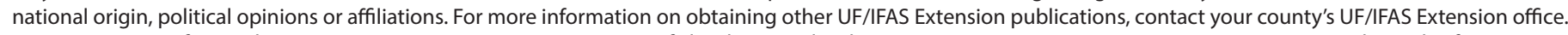
U.S. Department of Agriculture, UF/IFAS Extension Service, University of Florida, IFAS, Florida A \& M University Cooperative Extension Program, and Boards of County Commissioners Cooperating. Nick T. Place, dean for UF/IFAS Extension. 


\section{Finger Lime Origin}

The Australian finger lime (Microcitrus australasica) is native to the rainforests located in the coastal border regions of Queensland and New South Wales (NSW) in Australia (Hardy et al. 2010; Australian National Herbarium 2013). Finger lime is classified as a citrus fruit. Its taste has been described as a combination of lemon, lime, and grapefruit. The cylindrical fruit, which comes in varied colors such as pink and green, grows to about three inches in length (comparable to a gherkin in size and shape and resembles the index finger, hence its name). The fruit consists of hundreds of tiny, tangy juice vesicles, which some refer to as citrus caviar due to their shape, desirability, and high price (Figure 1). Like other types of citrus fruit, finger limes have nutritional value, few calories, and a high vitamin content (MyFitnessPal.com 2017). Demand for finger lime in Australia has grown steadily since 2010, mainly because of its unique caviar-like pulp, attractive color range, and bushfood status (i.e., a food native to Australia and used as sustenance by Aboriginal Australians).

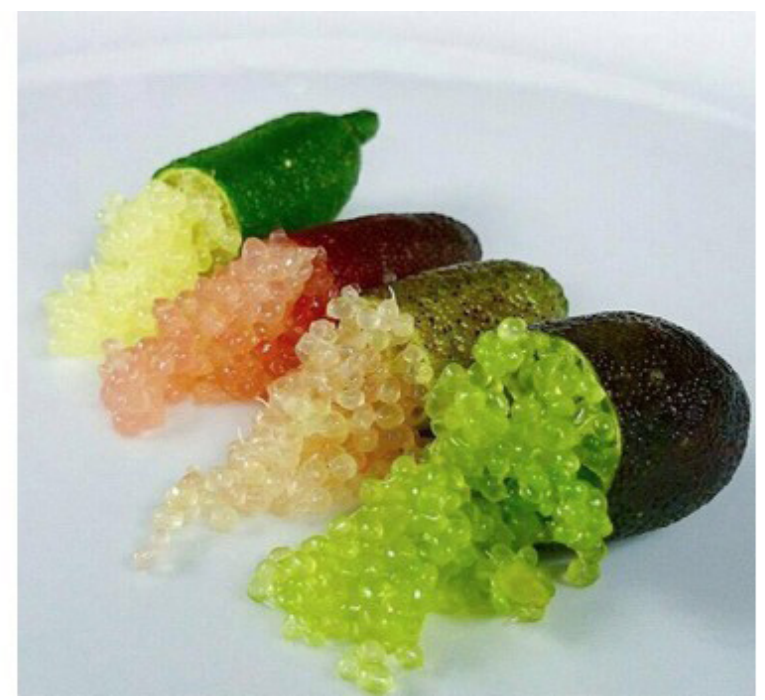

Figure 1. Finger lime fruit

Credits: USDA

\section{Finger Lime in the United States}

The United States Department of Agriculture first imported finger lime seeds and cuttings more than a century ago as a research subject, with the crop remaining at the research level into the twenty-first century. The University of California-Riverside (UC-Riverside) developed an interest in the crop and began rootstock trials and hybridization research experiments with finger lime trees in 1965. As part of the UC-Riverside Citrus Variety Collection, UC scientists have released finger lime budwood for California nurseries to use in propagating trees. California is the only US state that grows finger lime on a commercial basis, at around 15,000 finger lime trees (Karp 2009).

\section{Agroclimate Requirements, Intercultural Operations, and Estimated Economics of Production}

Ideally, finger lime planting sites should be frost-free and protected from prevailing winds. Commercial orchards do well if planted in full sun (Figure 2). Like all citrus varieties, finger lime requires well-drained soils. The trees are highly susceptible to wind and sunburn, so windbreaks should be established before planting. Finger lime is reported to require less fertilizer than other commercial citrus varieties partly due to less nutrient demand: the trees have smaller leaves and smaller canopy area (Osborne 2015). It is reported that growers use $25 \%-30 \%$ of the total annual amount of N-P-K fertilizer applied to other commercial citrus varieties. Yields vary with cultivar, but a well-managed 5-year-old tree can produce up to 44 pounds annually (Hardy et al. 2010).

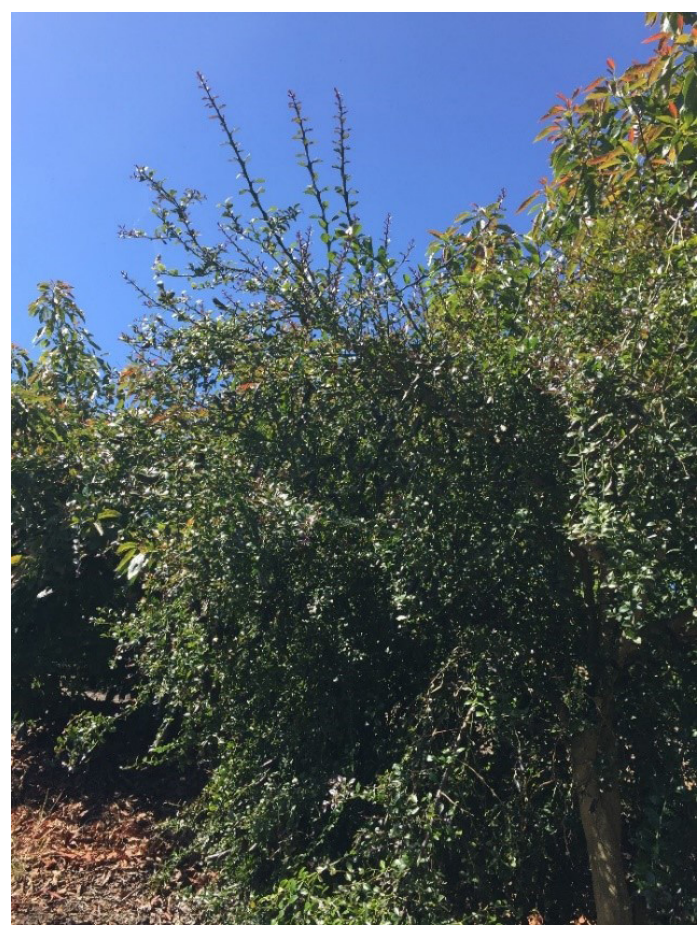

Figure 2. Finger lime orchard

Credits: Jeff Wasielewski, UF/IFAS Extension

Finger lime is very delicate and susceptible to skin damage, with close to $50 \%$ of the harvest ending up as second grade or processed fruit due to injury caused by its own thorns during harvesting. Apart from prospects of high returns, other attractive features of the crop include the fact that is reported to be highly resistant to Phytophthora citrophthora root disease. Preliminary studies have also indicated that finger lime is tolerant to Huanglongbing (HLB), or citrus 
greening (Chandrika et al. 2016), a devastating citrus disease that is now endemic in Florida. Field trials to evaluate the appropriate rootstock and nutritional requirements for optimum plant growth are currently underway at the University of Florida's Citrus Research and Education Center (CREC) in Lake Alfred, FL (Dutt et al. 2017).

Varieties currently available to growers include DPI-50-36, DPI-205-1, and DPI-205-4. However, these varieties are the typical non-pigmented type. CREC is in the process of importing the commercial red-pigmented type grown in California (VI 697 accession) to evaluate a population of seedlings from this and other red-pigmented finger limes.

The growth habit of finger limes can range from a large shrub to a small tree (up to 6 meters) (Australian National Herbarium); therefore, for the purpose of the desk analysis that follows, we compare it to that of 'Tahiti' limes, which are somewhat similar in size. Using the average planting density for a 'Tahiti' lime orchard in Florida of 145 trees per acre (estimated spacing of 20 feet between rows and 15 feet within rows) (Morton 1987; Mossler and Nesheim 2009), and with an estimated yield of 44 pounds and a packout rate of $75 \%$, the marketable yield is estimated at around 4,785 pounds per acre. It should be noted that some growers in California are using spacing of 12 feet by 12 feet, or about 300 trees per acre. Furthermore, assuming a conservative farm gate price of $\$ 12$ per pound (estimated at $40 \%$ of the retail price of $\$ 30$ per pound for small [0.37 ounces per fruit]), we arrive at a gross revenue of about $\$ 57,420$ per acre. In order to arrive at net return per acre, we further assumed the production cost to be around 50\% of gross revenue ( $47 \%$ based on earlier studies carried out on 'Tahiti' lime), given the high labor requirement for harvesting. Even with this assumption, the estimated net return would still be close to $\$ 28,700$ per acre. Again, it is worth emphasizing that these are conservative preliminary estimates and much research remains yet to be done on the economics of finger lime productions under Florida conditions.

\section{Marketing and Market Opportunity}

Australian government data estimate the total national production of finger limes at around 10 tons, with about half of the fruit exported to Europe and Asia (Hardy et al. 2015). The US domestic retail price ranges from $\$ 30$ per pound for the fruit ( 0.35 to 0.39 ounces) to about $\$ 50$ per pound for the premium fruit (weighing more than half of an ounce per fruit) (Fig Tree Farms 2017). Once harvested, finger lime has a four-week shelf-life if stored in a cool room. The fruit, which retains its shape and flavor when frozen, is available year-round (Hardy et. al. 2010) and can be a substitute to lemon and lime varieties, which do not sustain such prolonged freezing periods during storage after harvesting (Crane 2016; Simonne et al. 2016). Commercially, finger lime can also be used in a wide-range of pharmaceutical and nutraceutical products; however, information on market prices is not readily available.

Within the United States, finger lime is beginning to gain popularity and could eventually become more mainstream as crop supply increases and crop prices decrease. California's Central Valley between Visalia and Bakersfield is the main growing area for finger lime, with about 15,000 trees owned by less than a dozen growers. Due to its small-scale production, the fruit is somewhat difficult to find in the marketplace. The main distribution is in large metropolitan areas, where it is sold primarily to high-end retail markets and upscale hotels/bars/restaurants. Mixologists use finger lime fruit in drinks; chefs primarily use them in seafood and Asian Fusion recipes and as a caviar-type garnish (Schueller 2015). At certain markets in California, a oneounce container sells for as high as $\$ 8$ (Schuller 2015). The reason for such an exorbitant price is because production volumes are still small and demand outweighs supply. As mentioned earlier, around 50\% of the Australian finger lime production is exported to markets in Europe and Asia, where demand is growing; hence, the US market is not crowded.

\section{Concluding Remarks}

While commercial production of finger lime in Florida has not yet been undertaken, evidence suggests that it is likely to do well in this environment and possibly replace some of the existing crops. The varied ranges of the colors of fruit flesh and rind certainly make finger limes appealing to high-end hoteliers and those consumers wishing to try something new (Dutt et al. 2017). Moreover, with increased production, prices on the local market will likely decline somewhat further, stimulating local demand as it becomes accessible to a wider cross-section of consumers. The crop has several attractive features, including its tolerance to some of the most devastating citrus diseases and its relatively low fertilizer requirements. Most importantly, as our preliminary desk analysis reveals, the crop has the potential for high returns. Drawbacks include the current high retail price for the crop limiting growth in demand, labor requirements for harvesting the crop, and the need to optimize production practices. 
Challenges notwithstanding, the prospects for the finger lime industry look promising for Florida. Growers who would like more information on the agronomy of the crop, as well as where to obtain budwood planting material, may contact Dr. Manjul Dutt at the Citrus Research and Education Center in Lake Alfred, FL.

\section{References}

Chandrika, R., M.L. Keremane, S.E. Halbert, Y.P. Duan, M.L. Roose, E. Stover, and R.F. Lee. 2016. "Long-Term Field Evaluation Reveals Huanglongbing Resistance in Citrus Relatives." Plant Disease 100(9):1858-1869. https://doi. org/10.1094/PDIS-03-16-0271-RE

Crane, J.H. 2016. Lemon Growing in the Florida Home Landscape. HS1153. Gainesville, FL: University of Florida, Institute of Food and Agricultural Sciences. http://edis.ifas. ufl.edu/hs1153

Fig Tree Farms. 2017. California Finger Limes. Buy Now. http://www.fig-tree-farms.com/buy-now.html

Hardy, S., P. Wilk, J. Viola, and S. Rennie. 2010. Growing Australian native finger limes. Prime Facts. http://www.dpi. nsw.gov.au/_data/assets/pdf_file/0016/320272/growingaustralian-native-finger-limes.pdf

Karp, D. 2009. "Finger Lime: The Caviar of Citrus." Los Angeles Times, December 23. http://articles.latimes. com/2009/dec/23/food/la-fow-marketwatch18-2009dec23

MyFitnessPal.com. 2017. Calories in Fruit: Finger Lime. http://www.myfitnesspal.com/food/calories/26842158

Osborne, T. 2015. Australian Finger Lime Care. http:// tastylandscape.com/category/australian-finger-lime-care/

Schueller, R. 2015. Finger Lime: One of the

Most Expensive US Fruit Varieties. http://

www.freshplaza.com/article/150393/

Finger-lime-one-of-most-expensive-US-fruit-varieties

Shannon, M. 2003. "Challenges in Safeguarding the Greater Caribbean Basin Against Invasive Pests, Diseases, Weeds, and Other Agents: A Florida Perspective." Proceedings of Caribbean Food Crops Society 39(1): 1-5.

Simonne, A., L.B. Bobroff, A. Cooper, S. Poirier, M. Murphy, M.J. Oswald, and C. Procise. 2016. South Florida Tropicals: Lime. HE621. Gainesville, FL: University of Florida, Institute of Food and Agricultural Sciences. http:// edis.ifas.ufl.edu/he621 